九州霜会誌 $54(5): 483 \sim 486,2000$.

\title{
唾液分泌之体液調節との接点
}

\author{
稲 永 清 敏 \\ 九州歯科大学生理学講座 (主任：稲永 清敏教授)
}

平成 12 年 8 月 25 日受理

\section{Relationship between Salivary Secretion and Body Fluid Balance}

Kiyotoshi Inenaga

\begin{abstract}
Department of Physiology (Chief : Prof. Kiyotoshi Inenaga)
\end{abstract}
Kyushu Dental College, Kitakyushu, Japan

Sweating in exercise causes a loss of the body fluid and an increase of the plasma osmolality. Then we feel thirst. In general, people understand from their own experience that salivary secretion may decrease under such conditions. However, there is little evidence to show how the hyperosmosis induces a decreased salivary secretion. In this review, we clarify the control mechanism of salivary secretion by osmotic stimulation on the basis of our recent studies.

Key words : Salivary secretion/Body fluid balance/Thirst

はじめに

暑い夏の盛りに多くの汗をかくと喉がカラカラになっ てくる. この時, 浸透圧の上昇と体液量の減少がおこっ ている.このような体験は誰しももっているわけで, 汗 をかくときは唾液の分泌が悪くなっていそうだというこ とは経験的に判っている。しかし，唾液分泌と体液調節 の中枢性連関について詳細に調へた研究は少ない，本稿 では、これについてわれわれが行った最近の研究を概説 する.

\section{1．遗伝性多飲マウスの喠液腺異常}

遺伝性多飲マウス $(\mathrm{STR} / \mathrm{N})$ は, 正常かそれ以上の抗 利尿ホルモンを生成し分泌しているのにあ関わらず，多 飲多尿を有する ${ }^{1)}$. 水代謝中枢のアンギオテンシンやオ ピオイドに対する応答異常, 咽頭・喉頭領域の水情報受 容の異常, 腎臓におけるバゾプレッシン結合能の異常, 免疫系の異常などが報告されているが, 多飲性の決定的 な因子はまだ見つかっていない．STR/N というのは生 後すぐに多飲を示すのではなく経日的に多飲を示すよう
になってくる1).興味あることに, STR/N では多飲を示 す経日変化と相関して㐘槽骨の吸収が認められ2),この 時の STR/N の口腔内細菌相は歯周疾患における細菌相 と類似しているという報告がある゙3. 唾液腺の機能低下 は飲水行動を促す一つの因子であるから，われわれは STR/N の唾液腺の機能低下を疑い実験を行っだ).コン トロールとしてICR を用いた. その結果, STR/N の顎 下腺は, コントロールの ICR と較べ軽量であること, 約 2 倍の堅さであること，さらに行動実験より，一日絶食 すると ICR および STR/N 両方とも飲水量が減少する が, STR/N の飲水量は極端に減少すること, 通常の水 の給餌を行うとICR あ STR/N あ両者とす同じょうな 摂食量を示したが, 24 時間絶水中の摄食量はSTR/Nの ほうが極端に少ないこと，唾液腺を摘出した後の飲水量 の経日変化を調べると, ICR マウスは有意に増加したが STR/Nではほとんど変化しないことがわかった，さら に, ピロカルピン刺激による唾液分泌量の測定実験で, 多飲多尿を示す 6〜11 ヶ月齢のマウスと, 多飲を示して いない 8〜10 週齢の若いマウスと比較したところ，まだ 多飲を示していない 8〜10 週齢の若いマウスでは, ICR 
と較べピロカルピン剌激による唾液分泌量に差は認めら れないが，多飲多尿を示す 6〜11 ヶ月齡のマウスでは， ピロカルピン刺激による唾液分泌量に有意な差が認めら れた.これらのことにより，STR/N の刺激唾液分泌量 は加龄に伴い低下すること，即ち，STR/N の喠液分泌 機構が加齡により変化する可能性が示唆された. STR/ $\mathrm{N}$ のピロカルピン刺激によって分泌された唾液と血獎 の浸透圧は，いずれす ICR に較べて高かった。一般に腺 房細胞から導管に分泌された唾液の電解質成分が再吸収 されて血漿より浸透圧が低くなること，流速が遅いほど 再吸収が進み低調な唾液が分泌されることがわかってい る. STR/N の唾液分泌量は少ないので，より低調な唾 液浸透圧が期待されたが, 結果は予想に反していた. STR/N の血漿浸透圧が高いことが飲水を促す一因であ ることは，間違いないと考えられるが，唾液浸透生が高 いということも飲水を促す要因になっている可能性が示 唆された．また，STR/N は唾液腺導管での再吸収機構 に問題があるかあしれない.これらの結果, STR/Nの 唾液腺は機能低下しており，摄食中での飲水量の増加が 唾液分泌量の低下を補うために起こっていると考えられ る. 掑食に伴う唾液分泌量が十分ではないため，食物残 渣が口腔内に残り，迷周疾患様症状を呈した可能性があ る.

\section{2. 浸透圧刺激による中枢性喠液分泌減少}

血奬浸透圧の上昇は飲水を誘発する因子の一つであ る. 浸透圧が上昇すると末梢や中枢に存在する浸透圧受 容器で検出されて飲水行動が誘発される. 血漿浸透在之 唾液分泌量について調べた報告 ${ }^{5-8)}$ は散見されるが，中枢 におけるこれらの関連性についてはよくわかっていな い. 前述の STR/N の刺激唾液の減少は血漿浸透圧上昇 が原因なのかもしない，浸透圧刺激による唾液分泌量の 变化を直接計测するため，ラットを用いて実験を行っ た. ラットの唾液腺からの唾液の分泌量は最大でも一分 間に数 100 マイクロリットルと微量である.われわれは 唾液腺導管にポリエチレンチューブを挿入し, 出てきた 唾液量を圧トランスデューサーを用いて圧に変換し，そ の信号をコンピュータに入力した，また，過剩な泎が唾 液腺にかからないように，電磁弁を用いて出てきた唾液 を定期的に除去した。

ラット唾液腺より無麻酔無拘束で唾液分泌量測定を 行った実験は少ない．安静時唾液の分泌量は少ないが, 䬣を与えたときには刺激唾液が分泌され測定が可能で あった. 一定量の餌（200 mg あるいは $400 \mathrm{mg}$ )を一定
間隔（約 8 10 分占き）で絽り返し与えるという方法で 実験を行うと，一定量の慨を食べるときに分必される唾 液量や分泌速度は長時間（2 時間以上）一定であった. 人 $^{9)}$ や羊 ${ }^{10)}$ 等では偏側咬合が観察されているが，ラット で両側耳下腺からの唾液分泌を测定したところ，唾液分 泌量はすべての例で左右よく一致したので，両側咬合を 行っている割合が高いことがわかった。

ラット ${ }^{11)}$ やウス ${ }^{12)} 2$ 週間続けて液状食で飼育する と耳下腺の機能や形態に可塑的変化がおこると報告され ている. 実際にラットの耳下腺唾液分泌量が食慨の性状 によって変化するかどうかを調べてみると，固形食，粉 末食，液状食を与えたときの唾液分泌量は固形食で最あ 多く，液状食ではほとんど観察されないという結果が得 られた。ささらに，頢下腺と耳下腺唾液の食餉の性状によ る変化を調べてみると，㴿下腺からの唾液分泌は粉末食 と液状食で耳下腺唾液より多多いことや，グルーミング による唾液分泌は㴿下腺からは観察されるが，耳下腺唾 液分泌は諗められないことから，二つの唾液腺の機能に は違いがあることがわかる ${ }^{13)}$. 恝歯類は唾液を体毛に塗 布することによって体温調節をするが, この機構には䫇 下腺が選択的に㗢いているらしい ${ }^{14)}$.

さて，浸透圧刺激をすると耳下腺唾液はどうなるだろ うか. 腹腔内人の高張食塩水注入や絶水刺激を行うと, 唾液分泌速度は減少した. Nakahari $ら^{15)}$ は, 単離顎下腺 標本を用いて高張刺激を行うとアセチルコリンによって 誘発される唾液分泌量が減少することを報告している. これは，浸透圧刺激の唾液分泌に対する末梢性作用を強 く示唆する. 多分, 腹腔内高張食塩水注入および絶水刺 激実験で唾液分泌速度の減少の説明の一部しして，この 末梢性作用が考えられる，さて，中枢性作用はごうであ ろうか. 唾液分泌は下部脳幹の唾液核によって調節され ていることはよく知られたことである，さらに，上位中 枢である大脳皮質, 大脳辺縁系あるいは上部脳幹によっ ても影響を受ける．上部脳幹，特に視床下部や脳室周囲 系には浸透圧受容体が存在する。脳室内への高張液注入 や視床下部あるいは脳室周囲系の特定部位の浸透圧刺激 により，飲水行動が誘発され，抗利尿ホルモンの分泌促 進がおこる．唾液も体液の一部であることから体液調節 中枢之高次唾液分泌中枢はオーバーラップしていること が期待される. 最近, 顎下腺・舌下腺に擬狂犬病ウイル スを注入すると, そのウイルスは逆行性に軸索輸送さ れ，細胞体からさらに逆行性にシナプスを通り上部へと 輸送され, 視床下部·脳室周囲系 (室傍核·視床下部外側 野·正中核·脳弓下器官等) ニューロンが標識されると 


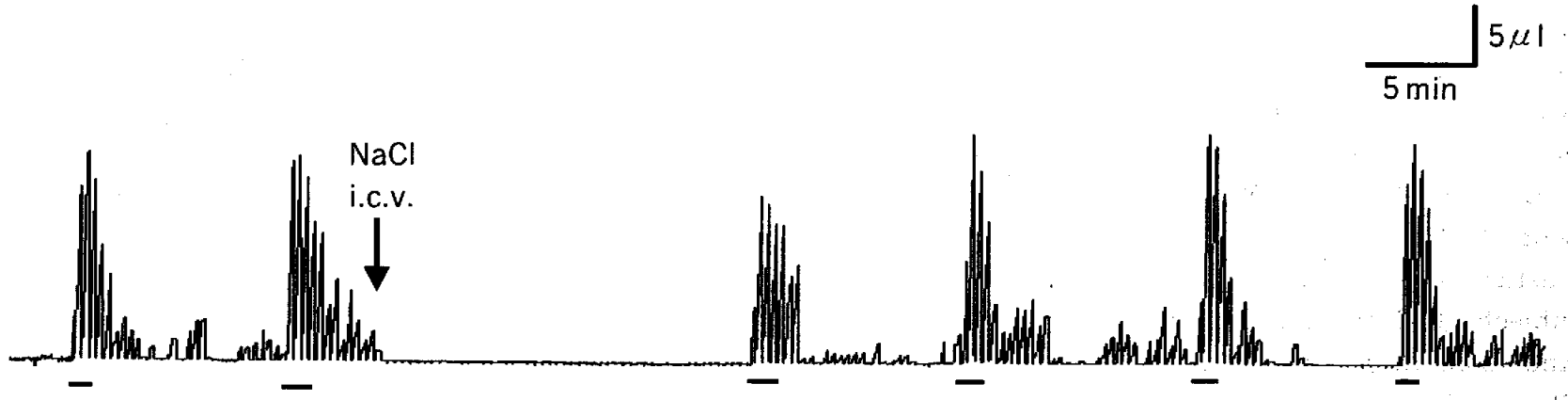

図 1 脳室内高張食塩水注入による耳下腺唾液分泌速度の減少.

ラット耳下腺導管にポリエチレンチューブを挿入し 20 秒ごとの唾液分泌量を測定した．下線は $200 \mathrm{mg} の$ 慨をラット。 が前肢で保持し口腔内に入れ終わるまでの時間を示す。矢印で高張食塩水（1 M, 毎分 $4 \mu 1$ を 5 分間注入）注入する. と, 唾液分必速度および喠液分泌量は減少した。

いう興味ある結果 ${ }^{16)}$ が得られている。これは，上記部位 ニューロンが唾液分泌調節を行っている可能性を強く示 唆している.

中枢性作用を調べるために，脳室内に高張食塩水を注 入すると, 注入直後の唾液分泌量および唾液分泌速度の 減少が観察された（図 1). 前述のことと考え合わせる と, 脳室内に注入した高張食塩水は脳室周囲系や視床下 部にある浸透圧受容ニューロンに作用し，唾液分泌を抑 制すると考えられる．飲水行動は，喉の口渴感を伴って 誘起される，口渴感の一部は唾液分泌減少によるすのと 推察される.

\section{3. 高次唾液分泌調節部位での浸透圧受容}

視床下部や脳室周囲系に浸透圧受容ニューロンが存在 することが判っている ${ }^{17)}$. 神経分泌ニューロンの浸透圧 受容機構の詳細な解析によると, 浸透圧上昇は細胞の膜 を収縮させるように働くが，その力により非選択性陽イ オンチャネルが開口するという。われわれは, 脳スライ ス標本を用い, 高次唾液分泌調節部位の一つであると考 えられる脳弓下器官ニューロンが浸透圧変化を検出する 可能性を示す実験結果を得た. 今後, このニューロンが 神経分泌ニューロンと同じような浸透圧受容機構を有す るか否かを検討する必要がある.

\section{4.おわりに}

体液調節は, 動物が生きていくうえで最あ重要な調節 機構である. 様々な代償機構が働くため, 体液調節機構 の研究を複雑なあのにしている，本稿では，血中浸透圧 が上昇すると末梢性・中枢性に作用し，唾液分泌を減少 させることによって飲水行動の発現を促進させる可能性
について述べた.

歯科領域の立場から唾液分泌量が体液浸透圧により影 響されるということを, 加齢変化加ら観察すると興味深 い. 生理的な加齢現象として，人は歳をとってくると体 液の浸透圧は上昇し，体重に占める体液量の割合は減少 する. 加齢により唾液分泌量が変化するか否か論争の渦 中にあるが，本稿で述べた体液調節系と唾液分泌連関の 立場から, 安静時唾液や刺激唾液の加齢的な变化をるう 一度見直す必要がある。

\section{引用文献}

1) Silverstein, E., Sokoloff, L., Mickelsen, O. and Jay, G. E. J.: Primary polydipsia and hydronephrosis in an inbred strain of mice. Am. J. Pathol. 38: 143-159, 1961.

2) Messer, H. H. : Alveolar bone loss in a strain of mice. J. Periodontal Res. 15: 193-205, 1980.

3) Wolf, L. F., Krupp, M. J. and Liljemark, W. F.: Microbial changes associated with advancing periodontitis in STR/N mice. J. Periodontal Res. 20: 378$385,1985$.

4) Hamada, A., Inenaga, K., Nakamura, S., Terashita, M. and Yamashita, H. : Disorder of salivary secretion in inbred polydipsic mouse. Am. J. Physiol. Regul. Integr. Comp. Physiol. 278: R817-823, 2000.

5) Olsson, K.: Influence of altered CSF solute composition on parotid salivary secretion in goats. Acta Physiol. Scand. 97: 196-201, 1976.

6) Warner, A. C. and Stacy, B. D.: Influence of ruminal and plasma osmotic pressure on salivary secretion in sheep. Q. J. Exp. Physiol. Cogn. Med. Sci. 62 : 133-142, 1977.

7) Silanikove, N. and Tadmor, A.: Rumen volume, saliva flow rate, and systemic fluid homeostasis in 
dehydrated cattle. Am. J. Physiol. 256: R 809-815, 1989.

8 ) Ship, J. A. and Fischer, D. J.: The relationship between dehydration and parotid salivary gland function in young and older healthy adults. J. Gerontol. A Biol. Sci. Med. Sci. 52: M310-319, 1997.

9) Scott, B. J., Hassanwalia, R, and Linden, R. W.: The masticatory-parotid salivary reflex in edentulous subjects. J. Oral Rehabil. 25 : 28-33, 1998.

10) Anderson, D. J., Hector, M. P. and Linden, R. W.: The possible relation between mastication and parotid secretion in the rabbit. J. Physiol. (Lond.) $364: 19$ $29,1985$.

11) Kurahashi, M. and Inomata, K.: Effects of dietary consistency and water content on parotid amylase secretion and gastric starch digestion in rats. Arch. Oral Biol. 44: 1013-1019, 1999.

12) Murai, S., Saito, H., Nakamura, K., Masuda, Y. and Itoh, T.: The effects of a long-term powdered diet on the amounts of two principal neurotransmitters in the major salivary glands and on stimulated salivary secretion in mice. Methods Find. Exp. Clin. Pharmacol. 18 : 459-463, 1996.
13) Matsuo, R., Yamamoto, T., Ikehara, A. and Nakamura, O.: Effect of salivation on neural taste responses in freely moving rats : analyses of salivary secretion and taste responses of the chorda tympani nerve. Brain Res. 649: 136-146, 1994.

14) Yanase, M., Kanosue, K., Yasuda, H. and Tanaka, H.: Salivary secretion and grooming behaviour during heat exposure in freely moving rats. J Physiol (Lond) 432: 585-592, 1991.

15) Nakahari, T., Steward, M. C., Yoshida, H. and Imai, Y.: Osmotic flow transients during acetylcholine stimulation in the perfused rat submandibular gland. Exp. Physiol. 82 : 55-70, 1997.

16) Hubschle, T., McKinley, M. J. and Oldfield, B. J.: Efferent connections of the lamina terminalis, the preoptic area and the insular cortex to submandibular and sublingual gland of the rat traced with pseudorabies virus. Brain Res. 806: 219-231, 1998.

17) Bourque, C. W., Oliet, S. H. R. and Richard, D. : Osmoreceptors, osmoreception, and osmoregulation. In : Frontiers in Neuroendocrinology Academic Press, Orland, 1994, 231-274. 